\title{
AGRO-BASED SMART CITY KOTA BATU: IMPLEMENTASI DAN TANTANGAN
}

\author{
Naufal Fikhri Khairi dan Jordan Aria Adibrata \\ Indonesia International Studies Academic Utilization Community (IISAUC) Malang
}

\begin{abstract}
The purpose of this study is to explain the process of applying the concept of smart city in Batu that focuses on agriculture. Smart city is a rising concept to be discussed, it is because many countries apply this concept in developing their cities using ICT (Information and Communication Technology). Indonesia became one of the countries that participated in implementing the concept of smart city, through the " 100 Smart City Movement" program. Batu City is one of the cities that applies the concept, but there is an interesting thing that they focus on the concept of agriculture as their main source. The study was a qualitative descriptive study using data collection techniques in the form of interviews. Advocacy Coalition Theory will be a tool in explaining the application of the Batu City smart city policy, and can map the actors and plot of the policy making. The results obtained are Batu City smart city policy focusing on agriculture because it wants to maximize the potential of Batu City in agriculture by giving birth to an online transaction system between farmers and consumers to prevent the practice of middlemen. But the realization of smart city in Batu City still has various obstacles in its implementation, including community participation and patterns of cooperation that have not been effective.
\end{abstract}

\begin{abstract}
Abstrak: Tujuan dari penelitian ini yaitu untuk menjelaskan mengenai proses penerapan konsep smart city di Kota Batu yang berfokus di bidang pertanian. Smart city merupakan konsep yang sedang naik daun untuk dibahas, hal tersebut dikarenakan banyak negara-negara menerapkan konsep ini dalam membangun perkotaannya dengan menggunakan TIK (Teknologi Informasi dan Komunikasi). Indonesia menjadi salah satu negara yang ikut menerapkan konsep smart city, melalui program "Gerakan 100 Smart City". Kota Batu merupakan salah satu kota yang menerapkan konsep tersebut, akan tetapi terdapat hal yang menarik yakni mereka memfokuskan konsep tersebut pada bidang pertanian yang menjadi sumber utama mereka. Penelitian bersifat deskriptif kualitatif dengan menggunakan teknik pengumpulan data berupa wawancara. Teori Koalisi Advokasi akan menjadi alat dalam menjelaskan penerapan kebijakan smart city Kota Batu, serta dapat memetakan aktor dan alur dari terbuatnya kebijakan tersebut. Hasil yang didapatkan yakni kebijakan smart city Kota Batu berfokus kepada bidang pertanian dikarenakan ingin memaksimalkan potensi Kota Batu dalam bidang pertanian dengan melahirkan sistem transaksi lansung (online) antara petani dan konsumen untuk mencegah praktek tengkulak. Tetapi realisasi smart city di Kota Batu masih memiliki bebagai hambatan dalam implementasinya, meliputi partisipasi masyarakat dan pola kerjasama yang belum efektif.
\end{abstract}

Kata Kunci: kota batu, smart city, pertanian, teknologi informasi

\section{PENDAHULUAN}

Smart city merupakan istilah yang digagas pertamakali oleh IBM (International Business Machine Corporations) pada tahun 1998. IBM mendefinisikan smart city sebagai kota yang mampu memanfaatkan secara optimal seluruh informasi yang tersedia dan saling berhubungan, untuk memahami dan mengendalikan operasi, serta mengoptimalkan penggunaan sumber daya terbatas (Patel \& Padhya, 2014). CISCO mendefinisikan smart city sebagai pengadobsian solusi yang terukur dengan memanfaatkan teknologi informasi dan komunikasi untuk meningkatkan efisiensi, pengurangan biaya, dan kualitas hidup. The British Standards Institute memberikan pengertian smart city sebagai integrasi yang efektif dengan mencakup infrastruktur fisik, sistem digital, serta keterampilan SDM (sumber daya manusia) untuk membangun lingkungan di masa depan yang berkelanjutan, makmur, dan inklusif (Patel \& Padhya, 2014).

Penerapan smart city telah dilakukan oleh berbagai kota di berbagai negara-negara di dunia, diantaranya yaitu Barcelona (Spanyol), Bristol (Inggris), Cologne (Jerman), Lisbon (Portugal), Eindhoven (Belanda), Stockholm (Swedia), dan lain-lain (EU Smart Cities Information System, 2015). Tersebarnya konsep pembangunan kota-kota ini merupakan salah satu dampak dari berkembangnya TIK (Tek- 
nologi Informasi dan Komunikasi) yang mana semakin berjalannya zaman semakin canggih, sehingga dapat membantu hidup manusia menjadi lebih mudah. Dengan adanya keuntungan yang besar tersebut, penerapan smart city dapat membuat kehidupan perkotaan yang mencakup masyarakat dan sistem pemerintahan menjadi lebih mudah.

Indonesia juga adalah salah satu negara yang mengimplementasikan smart city, hal ini dibuktikan dengan adanya program "gerakan menuju 100 smart city" yang merupakan kerjasama antara Kementrian Komunikasi dan Informatika, Kementrian Dalam Negeri, Kementrian PUPR, Bapennas, dan Kantor Staff Kepresidenan, dimana pada program ini Indonesia berkomitmen membangun sebanyak-banyaknya kota dengan konsep smart city, hal ini terbukti dengan sukses dibangunnya berbagai kota dengan konsep ini yaitu Surabaya, Bandung, Bekasi, Bogor, Batu dan lain-lain (Kementrian Komunikasi dan Informatika Republik Indonesia, 2016).

Kota Batu menerapkan konsep smart city dalam program pembangunannya sejak tahun 2017, yaitu dengan adanya Peraturan Walikota (Perwali) No.78 tahun 2017, yang berisi Master Plan Smart City Kota Batu. Diterapkannya smart city di Kota Batu bertujuan untuk mengelola sumber daya alam, pemberian informasi yang tepat, efisiensi operasi perkotaan, daya saing ekonomi, peningkatan jasa, serta memenuhi kebutuhan masyarakat Kota Batu lainnya untuk sepanjang generasi sekarang maupun selanjutnya. Dengan diterapkannya konsep smart city, diharapkan masyarakat berpartisipasi aktif dalam pengelolaan kota dengan cara memberikan feedback (umpan balik) baik ke sektor pelayanan privat maupun publik (Pemerintah Kota Batu, 2017).

Penerapan konsep smart city di Kota Batu terlihat dari terbentuknya beberapa smart apps yang dapat diakses secara online ynag mana merupakan ciri dari penggunaak TIK (Teknologi Informasi dan Komunikasi). Aplikasiaplikasi tersebut yaitu: 1) Among Tani, merupakan aplikasi yang khusus mengatur bidang pertanian dengan cara memajang hasil-hasil dan harga dari produksi pertanian Kota Batu secara online, selain itu pengguna aplikasi ini dapat berupa penjual, pembeli, dan ahli tani yang bertugas memberikan informasi mengenai pertanian; 2) Among Warga, adalah aplikasi yang menjadi sarana masyarakat Kota Batu dalam memberikan aspirasinya kepada pemerintah Kota Batu mengenai kejadian di kota, yang mana akan segera ditangani oleh dinas yang terkait; 3) Among Kota, merupakan aplikasi yang memberikan informasi mengenai berita terbaru dari Kota Batu, selain itu memberitahukan pembaca mengenai event, tempat wisata, rute kota, kontak darurat, dan lain-lain yang mana akan sangat berguna bagi wisatawan (Pemerintah Kota Batu, 2017).

Kota Batu sebelum ditetapkan smart city, banyak dari masyarakatnya yang masih berada pada keterbelakangan dalam hal pemberdayaan. Misalnya seperti para petani, tidak sedikit para petani di Kota Batu yang mengalami kerugian akibat dari banyaknya rantai pendistribusian dari hasil panen petani (Prayoga, 2017). Hal ini kemudian menyebabkan hasil panen petani terjual dengan sangat murah, karena yang menentukan harga panen bukanlah petani itu sendiri melainkan para tengkulak itu karena para petani tidak mengetahui harga pasarannya (Anggreini \& Baladina, 2017). Ini tidak hanya terjadi pada petani buah melainkan juga petani sayuran, padi, dan bunga (Puspasari, Rosihan, \& Fitria, 2017).

Selain itu permasalahan lain seperti kurangnya pengetahuan masyarakat Kota Batu terkait dengan hal pertanian mengakibatkan mereka banyak mengalami kerugian. Misalnya sepeti minimnya pengetahuan terkait dengan bibit tanaman yang baik dan berkualitas serta obat obatan untuk pemusnah hama (Putri, 2017). Kurangnya pengetahuan ini disebabkan oleh rendahnya kualitas sumber daya manusia(SDM), infrastruktur, intensitas pemanfaatan akses internet, serta rendahnya regenerasi dikalangan petani (Arifianto, 2016). Sehingga hal-hal tersebut membuat petani di Kota Batu mengalami begitu banyak kerugian padahal Kota Batu memiliki peluang besaruntuk bisa menjadi tempat yang bisa memberikan keuntungan besar. 
Konsep smart city merupakan hal yang kompleks untuk dijelaskan, hal ini dikarenakan banyaknya aspek yang berdiri di dalamnya. Namun, dalam referensi ini diberikan definisi mengenai smart city, yaitu merupakan kota yang memiliki kinerja baik dalam memandang perencanaan kedepan dengan mengacu kepada enam karakteristik (smart economy, smart people, smart governance, smart mobility, smart environment, smart living) dibangun dengan kombinasi "cerdas" dari sumbangan dan kegiatan menentukan nasib sendiri, mandiri, dan kesadaran masyarakat.

Lombardi mengidentifikasi enam dimensi smart city yang berhubungan dengan kehidupan perkotaan (urban live), yaitu dimana smart economy adalah industri, smart people yang merupakan edukasi, smart governance merujuk kepada e-democracy, smart mobility yang merupakan logistik dan infrastruktur, smart environment yaitu efisiensi dan sustansibility, dan smart living yang mengarah kepada keamanan dan kualitas (Lombardia, Giordano, Farouhc, \& Yousef, 2012).

Giffinger mengidentifikasi karakteristik atau dimensi dari smart city menjadi beberapa faktor yaitu: 1) bidang ekonomi, mencakup produktivitas, merek dagang, kewirausahaan, fleksibilitas pasar tenaga kerja. 2) bidang sosial, mencakup pembelajaran, pluralitas sosial dan etnis, fleksibilitas, kreativitas, partisipasi dalam kehidupan publik. 3) bidang pemerintahan, mencakup partisipasi masyarakat dalam pengambilan keputusan, pemerintahan yang transparan, layanan publik dan sosial, strategi dan perspektif politik. 4) bidang mobilitas, mencakup aksesibilitas lokal, aksesibilitas internasional, ketersediaan infrastruktur TIK, sistem transportasi yang berkelanjutan dan aman. 5) bidang lingkungan, mencakupkondisialam yang menarik, polusi, perlindungan lingkungan, pengeloalaan sumber daya yang berkelanjutan.6) bidang budaya, mencakup fasilitas budaya, kondisi kesehatan, keamanan individu, kualitas perumahan, fasilitas pendidikan, daya tarik wisata, dan kohesi sosial (Giffinger, et. al., 2007).

Penelitian ini menggunakan berbagai Referensi literatur berupa penelitian terdahulu yang berkaitan dengan topik smart city di Indonesia sebagai bahan pembanding yang akan merujuk kepada letak penelitian ini. Penelitian pertama yaitu "Implementasi Kebijakan Smart City di Kota Bandung" oleh Siti Widharetno Mursalim" (Mursalim, 2017). Penelitian ini menjelaskan mengenai penerapan konsep smart city di Kota Bandung, yang mana telah berlangsung sejak 2015 hingga sekarang. Kota Bandung berhasil menjadi salah satu juara pada Smart City Award di tahun 2015 yang diselenggarakan oleh majalah Asia's Tech Ecosystem, hal tersebut dikarenakan bandung dinilai berhasil dalam menangani berbagai masalah perkotaan dengan menerapkan aspek-aspek smart city.

Penelitian kedua yaitu "Menuju Kota Cerdas: Pelajaran dari Konsep Smart City yang Diterapkan di Jakarta dan Surabaya" oleh Kurnia Novianti dan Choerunisa Noor Syahid (Novianti \& Syahid, 2017). Pada penelitian ini menjelaskan mengenai pendekatan kota Jakarta dan Surabaya yang hampir sama dalam menerapkan konsep Smart City. Keduanya menekankan bahwa kerjasama antara pemangku kebijakan dan antar kota yang saling terhubung harus saling berkesinambungan demi terwujudnya Smart City. Untuk langkah mewujudkan konsep tersebut, kedua kota melakukan pendekatan melalui teknologi. Yakni Jakarta menggandeng perusahaan aplikasi yakni PT. Qlue Indonesia untuk menyediakan aplikasi Qlue yang dapat diunduh melalui berbagai platform. Aplikasi Qlue sendiri merupakan aplikasi pengaduan warga yang dirancang oleh Pemprov DKI pada masa kepemimpinan Ahok (Sutari, 2018).

Melalui jurnal yang disusun oleh Didi Kurnaedi berjudul "Penerapan "LIVE" Smart City Kota Tangerang" menjelaskan tentang komponen LIVE pada konsep smart city Kota Tangerang yang dipandang sebagai solusi inovatif dalam memecahkan masalah perkotaan (Kurnaedi, 2017). LIVE berarti masyarakat dapat mengakses dan memberikan informasi pada database kota yang dihimpun melalui sensor yang terpasang disetiap sudut kota dan diolah dengan aplikasi yang cerdas. Tujuan dengan adanya komponen ini adalah untuk menciptakan 
Kota Tangerang yang penuh dengan kemajuan teknologi, ekonomi, sosial politik, serta mampu untuk menjadikan sebagai kota yang hijau dan layak huni bagi masyarakatnya. Dalam penelitian ini, dengan adanya komponen LIVE ini masyarakat merasa puas dengan kualitas hidup di Kota Tangerang.

Dari ketiga penelitian di atas dapat ditarik sebuah benang merah, yakni smart city merupakan sebuah kota yang harus terintegrasi secara TIK (teknolologi, informasi, dan komunikasi) yang dapat meningkatkan fungsi dari sebuah kota. Penelitian tersebut mengkaji tentang kotakota besar di Indonesia seperti Jakarta, Surabaya, dan Bandung yang menerapkan smart city. Berdasarkan penelitian tersebut, kami mengambil kesimpulan yang mana membuat penelitian kami berbeda dari penelitian-penelitian tersebut. Pertama, penelitian-penelitian yang ada hanya mengkaji kota-kota besar di Indonesia, sedangkan kami mengkaji penerapan smart city Kota Batu yang memiliki wilayah yang tidak terlalu luas. Kedua, penelitian-penelitian yang ada hanya membahas perkembangan kota-kota yang menerapkan smart city secara general, sedangkan kami mempunyai fokus yang lebih kecil yaitu dengan mengkaji bidang agroteknologi smart city Kota Batu

Penelitian ini akan membahas mengenai penerapan Smart City di Kota Batu, Jawa Timur. Pemerintah Kota Batu menerapkan konsep smart city dengan berfokus pada bidang agroteknologi (pertanian). Hal tersebut menarik perhatian peneliti karena rata-rata penerapan konsep smart city mencakup berbagai aspek perkotaan secara umum, namun di Kota batu lebih menerapkan kepada bidang pertanian. Oleh karena itu, terdapat suatu pertanyaan penelitian yaitu "Mengapa Kota Batu menerapkan smart city yang berfokus kepada bidang pertanian

Penelitian ini memiliki tujuan untuk mengetahui konsep smart city yang diterapkan oleh Kota Batu, mengidentifikasikan aktor-aktor yang terlibat dalam pengimplementasian kebijakan ini, asal mula dari muncul hingga diterapkannya konsep tersebut di Kota Batu, serta mengkaji fenomena smart city ini dengan menggunakan pendekatan intermestik. Pendekatan ini sendiri berasal dari kata "internasional" dan "domestik" dan disingkat menjadi intermestik, yang membahas tentang proses penyerapan ide / norma / kebijakan dari luar (dunia internasional) menuju ke dalam negeri dan diimplementasikan serta sebaliknya. Selain itu, peneliti akan memberikan solusi terkait permasalahan yang ditemukan.

\section{METODE}

Penelitian ini menggunakan metode penulisan kualitatif. Pengertian dari metode ini sendiri adalah metode yang penelitiannya dilakukan pada kondisi yang alamiah (natural setting); disebut juga sebagai metode etnographi, karena pada awalnya metode ini lebih banyak digunakan untuk penelitian bidang antropologi budaya; disebut sebagai metode kualitatif, karena data yang terkumpul dan analisisnya lebih bersifat kualitatif(Sugiono, 2008). Metode penelitian ini lebih mengarah kepada mencari arti, memahami (understanding) gejala, fenomena, peristiwa, selain itu dalam metode ini juga dapat memahami arti terdalam serta esensi yang terdapat dari fenomena, peristiwa, dan kejadian (Raco, 2010).

Pengumpulan data menggunakan teknik wawancara, yang mana hal ini bertujuan untuk mendapatkan data secara first-hand. Teknik wawancara adalah suatu kegiatan yang dilakukan untuk mendapatkan informasi secara langsung dengan mengungkapkan pertanyaan-pertanyaan pada responden (Subagyo, 2011). Wawancara bermakna berhadapan langsung antara interviewer dengan responden, dan kegiatannya dilakukan secara lisan. Pada penelitian ini kami mewawancarai Bapak Robert selaku staff di bidang Jaringan A plikasi dan Infrastruktur seksi E-Gov (electronic government) dan pemberdayaan TIK (Teknologi Informasidan Komunikasi). Digunakanya teknik ini diharapkan mampu menambah keorisinalitasan penelitian ini.

\section{HASIL DAN PEMBAHASAN}

Dalam proses pembangunan smart city, terdapat beberapa aktor serta unsur yang ikut andil dalam berjalannya konsep ini. Smart city Kota Batu dibangun atas 3 (tiga) pilar yang terdiri dari: teknologi, sumberdaya manusia, serta 
masyarakat. Dibawah pilar sumberdaya manusia jika kita breakdown lagi, terdapat 3 (tiga) aktor yakni: pemerintah, pelaku usaha / bisnis, serta infrastruktur. Disini pemerintah tidak dapat menjadi single actor / aktor tunggal karena butuh sokongan dari masyarakat serta pelaku usaha agar smart city ini berjalan. Partisipasi masyarakat juga menjadi penting karena mereka lah yang menentukan tentang berhasil/ tidaknya smart city itu sendiri.

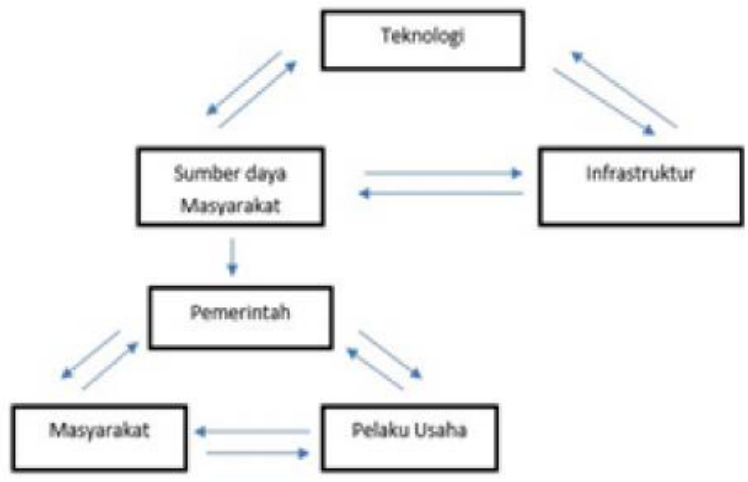

Gambar 1. Diagram Pilar Smart City Kota Batu

Melalui Teori Koalisi Advokasi, penulis dapat memberikan gambaran serta mengidentifikasikan aktor-aktor yang terlibat. Dalam teori tersebut disebutkan bahwa proses kebijakan tersebut meliputi aktor-aktor iron triangle seperti birokrasi, parlemen, dan kelompok kepentingan serta adanya aktor akademis seperti lembaga think-tank dan peneliti, dan lain-lain yang nantinya akan membentuk koalisi-koalisi advokasi. Berdasarkan kasus yang penulis angkat, maka aktor yang terlibat ialah pemerintah serta PT. Lintas Arta yang masuk dalam Issued Networks serta para pelaku usaha yang terdiri dari para petani dan lain-lain yang disebut technopols karena memiliki concern yang sama yakni dalam bidang pertanian, serta bidang yang lain.

Issued networks serta technopols inilah yang bekerja sebagai aktor dalam proses perubahan kebijakan dalam smart city Kota Batu ini. Kedua unsur ini saling memberikan input serta output satu sama lain demi terciptanya kesinergisan terhadap adanya kebijakan-kebijakan yang dibuat. Kesinergisan tersebut melambangkan serta menghasilkan kebijakan yang dapat diterima oleh berbagai kalangan di Kota Batu.
Jika kebijakan tersebut disetujui oleh khalayak, maka akan menciptakan kestabilan diberbagai tingkatan seperti pemerintah, masyarakat, serta pelaku usaha.

Jika dibedah lebih lanjut, maka secara tidak langsung Kota Batu ini memliki unsur intermestik didalam penerapannya. Apabila diilustrasikan melalui diagram, maka akan menjadi seperti ini:

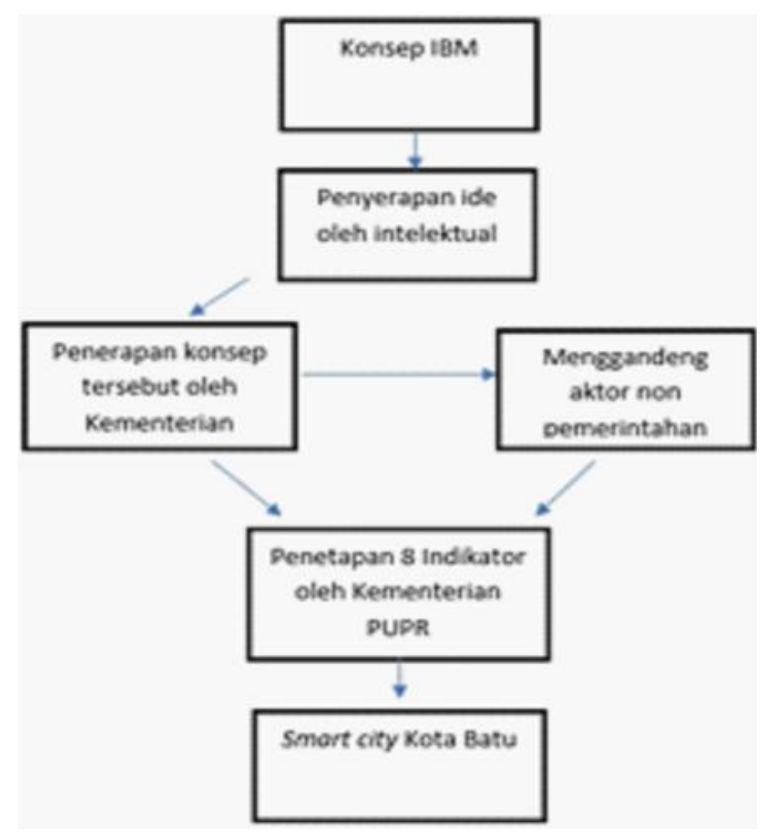

Gambar 2. Ilustrasi Asal Muasal Penerapan Smart City Kota Batu

Walaupun begitu, proses intermestik ini dapat dilihat dengan adanya proses penyerapan ide dari konsep IBM kedalam konsep yang telah ditetapkan oleh kementerian. Kota Batu secara tidak langsung mendapat ide smart city melalui adanya proses penyerapan diatas. Sehingga, smart city Kota Batu terbentuk karena ia menjadi eksekutor dalam penerapan kebijakan tersebut.

Masuknya konsep smart city di Indonesia ini juga merupakan andil dari aktor intelektual yang juga turut mengembangkan konsep smart city oleh IBM agar menjadi suatu konsep yang lebih relevan jika diterapkan di Indonesia. Suhono S. Supangkat, merupakan intelektual dibalik diterapkannya konsep ini di Indonesia (Devega, 2019). Gagasan smart city yang digaungkan olehnya pun berhasil diadopsi oleh kementerian-kementerian terkait di Indonesia untuk proses realisasi dengan mewujudkan 
program “Gerakan Menuju 100 Smart City”. Secara konsep, ini tidaklah jauh berbeda dari milik IBM sebelumnya, tetapi ada beberapa modifikasi agar sesuai dengan keadaan di Indonesia.

Menurut Suhono, smart city haruslah memiliki beberapa komponen pendukung seperti: smart economy, smart people, smart governance, smart government, smart mobility, smart environtment, dan smart living (Devega, 2019). Oleh karena itu konsep ini merupakan solusi untuk mengatasi masalah perkotaan yang dihadapi oleh warga. Selain itu sistem TIK menjadi salah satu komponen yang vital dalam smart city. Karena pada dasarnya tujuan dari adanya TIK sendiri untuk membuat sebuah kota menjadi lebih efektif serta efisien dalam berbagai hal.

Smart city di Batu sendiri merupakan hasil dari penerapan kebijakan "Gerakan Menuju 100 Smart City" yang ditetapkan oleh Kementerian Pekerjaan Umum dan Perumahan Rakyat (PUPR) (Biro Komunikasi Kementerian PUPR, 2019). Ada delapan indikator smart city yang telah dikembangkan oleh kementerian tersebut berdasarkan buah pikir dari Suhono tentang konsep smart city. Indikator tersebut adalah smart development planning, smart green open space, smart transportation, smart waste management, smart water management, smart building, dansmart energy. Sehingga, dapat disimpulkan bahwa pengembangan smart city di Kota Batu sendiri merupakan hasil dari pengaplikasian kedelapan indikator tersebut.

Ide smart city di Kota Batu ini diinisiasi pada tahun 2016 pada saat diselenggarakannya forum pertemuan antara Pemerintah Kota dengan Walikota, namun pada kurun waktu tersebut belum ditanggapi secara serius. Di awal tahun 2017 inisiasi ini didengungkan kembali, dan barulah pada pertengahan tahun 2017 ide tersebut ditindaklanjuti menuju proses realisasi saat adanya pertemuan smart city se-Indonesia di Palembang. Ide awal dari smart city ini pun berfokuskan pada masalah yang ada di Kota Batu saat itu, yakni di bidang pertanian serta bidang pengaduan warga. Kedua bidang inilah yang menjadi target dari Pemerintah Kota Batu agar masalah tersebut segera terpecahkan.

Bidang pertanian menjadi fokus pertama dari Pemerintah Kota Batu dalam usahanya untuk mendirikan smart city. Selama ini, masalahnya terletak pada rantai perdagangan pertanian diantara petani serta tengkulak. Petani merasa dirugikan karena tengkulak membeli hasil panen atau hasil pertanian dari para petani dengan harga yang sangat murah. Akibatnya, para petani tersebut tidak bisa mendapatkan keuntungan secara maksimal serta mengarah pada tingkat kemakmuran para petani tersebut. Karena bagaimana mungkin mereka mendapatkan hidup yang layak jika tidak diimbangi dengan pendapatan yang tinggi akibat dari aksi para tengkulak.

Selain itu, fokus pada bidang pertanian ini juga mengingat Kota Batu yang memiliki potensi di bidang tersebut. Kota ini ditopang dengan keadaan iklim yang dingin serta terletak di daerah yang tinggi dari permukaan laut. Kedua hal tersebut memungkinkan Kota Batu memiliki tanah yang subur serta produktif karena banyak komoditas panen dapat ditanam disana. Pertanian juga menjadi sumber mata pencaharian yang utama disana sehingga banyak warga yang bekerja serta menggantungkan hidupnya dari sektor pertanian.

Dalam mengatasi permasalahan tersebut, Pemerintah Kota Batu pun menginisiasikan dengan adanya sebuah platform/ wadah yang mana dapat mengakomodasi serta mempertemukan para petani dengan para pembeli secara langsung tanpa adanya pihak lain. Platform tersebut berwujud sebagai aplikasi yang dapat diunduh via smartphone yang berdampak pada tingginya aksesibilitas baik dari pihak petani maupun pihak pembeli. Aplikasi ini bernama "Among Tani" sebagai wujud dari implementasi dari konsep smart city. Tujuan dari pembuatan aplikasi ini ialah untuk memutus rantai perdagangan antara petani dengan tengkulak yang menyebabkan ketidakadilan serta kesenjangan. Ini seperti forum jual beli hasil pertanian secara daring diantara penjual dengan pembeli.

Adanya aplikasi tersebut akan menunjang fungsi dari konsep smart city itu sendiri. Karena 
akan menciptakan transparansi diantara aktoraktor yang terlibat dalam bidang perdangangan sebab pada aplikasi ini tercantum hasil produksi, luas lahan, serta harga yang dipatok oleh petani tersebut. Sehingga masyarakat dapat mengetahui informasi-informasi tersebut tanpa harus repot mencari informasi ke dinas terkait serta menjamin akan kepastian bagi para konsemen yang hendak membeli hasil pertanian tersebut. Aplikasi ini juga menguntungkan bagi para petani karena mereka dapat menghasilkan keuntungan yang lebih baik daripada jika berdagang dengan para tengkulak. Pada dasarnya, tengkulak akan membeli dari petani secara murah, lalu dijual dengan harga yang mahal agar dapat menguntungkan tengkulak tersebut dan ini jelas hanya menguntungkan satu pihak saja.

Walaupun Pemerintah Kota Batu melakukan hal yang revolusioner seperti diatas dalam bidang pertanian, nyatanya tidak membuat Kota Batu menjadi satu-satunya smart city yang berbasis agroteknologi di Indonesia. Banyak kota-kota lain di Indonesia yang memiliki potensi pertanian yang bagus sehingga pemerintahannya berusaha untuk memaksimalkan bidang yang ada tersebut. Sebut saja Kabupaten Banyuwangi yang memiliki potensi yang besar dalam bidang pertanian, serta Pemerintah Kabupaten Banyuwangi menggagas konsep "smart village" di desadesanya. Konsep ini bertujuan untuk menciptakan desa yang cerdas secara teknologi di bidang pertanian, serta memiliki tujuan untuk meningkatkan surplus hasil panen komoditas mereka sehingga akan tercipta kondisi desa yang makmur. Surplus pertanian tersebut didapatkan dengan hasil bantuan teknologi karena mengingat adanya hambatan bagi pertanian disana dengan adanya faktor tanah yang tidak bisa asal ditanami.

Selain itu, fokus kedua dari Pemerintah Kota Batu adalah tentang masalah pengaduan warga. Sebelum dicanangkannya konsep smart city ini, masyarakat yang ingin mengadu tentang masalah perkotaan tidak mendapatkan respon yang memuaskan dari pihak pemerintah kota. Hal ini menimbulkan kegusaran dari pihak warga masyarakat karena jika ingin melapor tentang adanya kerusakan infrastruktur tidak segera ditindaklanjuti. Alhasil untuk memecahkan ma- salah tersebut, digagaslah aplikasi pengaduan yang efektif bernama "Among Warga". Jadi masyarakat dapat mengadu secara daring dan akan ditanggapi secara sistematis oleh pihak Pemerintah Kota serta mendapatkan respon pengaduan yang cepat.

Adapun fokus tambahan dari Kota Batu yakni dibidang informasi tempat umum, tempat pariwisata, serta tempat penginapan bagi para wisatawan. Pemerintah Kota Batu membuat sebuah aplikasi yang bernama "Among Kota" yang bertujuan agar para wisatawan mendapatkan akses informasi seputar tempat-tempat tersebut. Dalam aplikasi juga diberikan informasi tentang fasilitas penginapan apa saja yang tersedia, harga, serta kamar yang tersedia. Hal ini dilakukan mengingat Kota Batu sekarang menjadi salah satu destinasi wisata yang populer di lingkup daerah maupun nasional.

Penerapan smart city di Kota Batu bukannya tanpa hambatan, melainkan ada faktor-faktor penghambat yang menjadi pekerjaan rumah bagi pemerintah kota. Seperti ketidakmampuan pemerintah kota untuk memperbaiki jalanan yang rusak dikarenakan dalam Kota Batu sendiri terdapat jalan provinsi, jalan negara, serta jalan kota itu sendiri. Sedangkan pemerintah kota hanya memiliki wewenang terhadap jalan kota saja. Hal ini dikarenakan pemerintah kota tidak memiliki wewenang yang luas terhadapjalanan di kota tersebut sehingga ditakutkan terjadi overlap wewenang.

Selain itu masalah besar yang dihadapi ialah pada bidang development dari aplikasi smart city Kota Batu itu sendiri. Aplikasi tersebut ternyata dikerjakan oleh pihak ketiga yang terlepas dari pemerintah yakni PT. Lintas Arta yang memenangkan tender pengadaan aplikasi tersebut. Pada nyatanya, aplikasi tersebut mengalami proses loading yang berat sehingga menyebabkan macet ketika membuka aplikasi tersebut. Hal ini mengakibatkan banyak masyarakat Kota Batu tidak mengunduh aplikasi tersebut karena problem-problem yang masih belum dipecahkan. Hanya 1/10 masyarakat Kota Batu yang mengunduh aplikasi tersebut dari total keseluruhan penduduk Kota Batu. 
Pihak Pemerintah Kota Batu sendiri tidak dapat memberikan input serta saran tentang masalah-masalah apa yang harus dipecahkan dalam aplikasi tersebut. Hal ini dikarenakan alur kolaborasi yang bersifat closed source sehingga murni aplikasi tersebut hanya dikerjakan oleh pihak PT. Lintas Arta. Saran dari penulis ialah sebaiknya pemerintah mengadakan kontrak ulang tentang pengadaan aplikasi tersebut yang mana pemerintah harus merevisi atau memperbaiki pola kerjasama yang awalnya bersifat closed source menjadi open source. Sehingga kedua belah pihak dapat saling memberikan feedback demi kelancaran aplikasi tersebut.

\section{SIMPULAN}

Smart city Kota Batu masih belum terealisasi secara baik, karena masih memiliki beberapa hambatan baik dalam masyarakat yakni partisasi dalam penggunaan aplikasi smart city maupun di dalam pemerintah itu sendiri yang mana kerjasama yang dilakukan dengan PT Lintasarta memiliki pola yang kurang efektif, sehingga menyebabkan ketidakefektifan aplikasi dalam penggunaannya. Namun, smart city Kota Batu jika dapat melalui masalah tersebut akan memiliki dampak balik yang sangat besar dalam bidang perkembangan ekonomi. Hal tersebut dikarenakan kebijakannya yang berfokus dalam agroteknologi akan membuat kerja petani menjadi lebih mudah, selain itu dapat mendorong kreativitas dan kefektifan dalam perdagnangan produk di Kota Batu.

\section{DAFTAR RUJUKAN}

Anggreini, M. D., \& Nur Baladina. 2017. Analisis Struktur, Perilaku dan Penampilan Pasar Kentang Di Desa Sumber Brantas, Kecamatan Bumiaji, Kota Batu. Jurnal Ekonomi Pertanian dan Agribisnis (JEPA), 1(2), 15.

Giffinger, R., Fertner, C., Kramar, H., Kalasek, R., Pichler-Milanoviæ, N., \& Meijers, E. 2007. Smart cities - Ranking of E uropean medium-sized cities. Vienna: Vienna UT.

Kitchin, R. 2014. Big Data, New Epistemologies and Paradigm Shifts. Big Data and
Society, 1(1), 1-14. doi:10.1177/ 2053951714528481

Kurnaedi, D. 2017. Penerapan "LIVE” Smart City Kota Tangerang. Jurnal TAM (Technology Acceptance Model), 8(1), 18-28.

Kurniawati, D. E. 2012. Pendekatan Intermestik Dalam Proses Perubahan Kebijakan: Sebuah Review Metodologis. Jurnal Studi Hubungan Internasional, 2(2), 158-159. Lombardia, P., Giordanob, S., Farouhc, H., \& Yousef, W. 2012. Modelling the Smart City Performance. Innovation-The European Journal of Social Science Research, 25(2).

Mursalim, S. W. 2017. Implementasi Kebijakan Smart City di Kota Bandung. Jurnal Ilmu Administratif, 12(1), 126-138.

Miimu, A. 2015. Smart City-Research Highlights. Grano: VTT Technical Research Centre of Finland Ltd.

Novianti, K., \& Syahid, C. N. 2017. Menuju Kota Cerdas: Pelajaran Dari Konsep Smart City Yang Diterapkan Di Jakarta Dan Surabaya. Prosiding Seminar Hari Tata Ruang (hal. 1-8). Malang: LIPI. Diambil kembali dari http://lipi.go.id/ publikasi/menuju-kota-cerdas-pelajarandari-konsep-smart-city-yang-diterapkandi-jakarta-dan-surabaya/14806

Raco, J. 2010. Metode Penelitian Kualitatif: Jenis, Karakter, dan Keunggulannya. Jakarta: Gramedia.

Subagyo, P. J. 2011. Metode Penelitian dalam Teori dan Praktek. Jakarta: Rineka Cipta. Sugiyono. 2008. Metode Penelitian Pendidikan: Pendekatan Kuantitatif, Kualitatif dan $R \& D$. Bandung: Alfabeta.

Patel, P. R., \& Padhya, H. J. 2014. Review paper for Smart City . International Journal of Advanced Research in Engineering, Science \& Management, 1-6.

Puspasari, E. D., Rosihan, \& Fitria. 2017. Analisis Efisiensi Pemasaran Bunga Mawar Potong (Studi Kasus Di Desa Gunungsari, Kecamatan Bumiaji, Kota Batu). Jurnal Ekonomi Pertanian dan Agribisnis (JEPA), 1(2), 18. 